\title{
Natural Capital as an Economic Concept, HISTORY AND CONTEMPORARY ISSUES
}

\author{
Antoine MISSEMER ${ }^{*}$
}

Full reference:

Missemer, Antoine. 2018. "Natural Capital as an Economic Concept, History and Contemporary Issues". Ecological Economics, 143, 90-96.

[https://doi.org/10.1016/j.ecolecon.2017.07.011]

The pagination of the published version is indicated in the margin.

\begin{abstract}
Natural capital is usually presented as a recent concept, used for the first time in the 1970s, adopted in an important contribution by David Pearce in 1988, and widely used by ecological economists in the early 1990s. First employed to incorporate natural constraints into the economic lexicon, and to oblige economists to take the environment into account, the concept has also been used to include the environment in narrow economic valuations. To take a global view of these controversial uses, this paper reconsiders the genesis of natural capital as an economic concept, not in its present-day form, but from its almost unknown, ancient origins in the 1900s-1910s, in the writing of Alvin S. Johnson. The article first sheds light on this historical and theoretical moment, and then shows how it can help interpret current controversies about natural capital.
\end{abstract}

Keywords: natural capital, history of economic thought, monetary valuation, theory of capital, John Bates Clark, Irving Fisher, Alvin S. Johnson

\footnotetext{
* [In 2018] CNRS, CIRED Paris - Centre international de recherche sur l'environnement et le développement (UMR 8568 CNRS/ENPC/EHESS/AgroParisTech/CIRAD), 45 bis av. de la Belle Gabrielle, 94736 Nogent-surMarne Cedex, France. E-mail: missemer@centre-cired.fr
} 


\section{Introduction}

In a classic article published in 2003, then republished in 2005, Maria Åkerman describes the origins of the natural capital concept, starting her story in the 1980s. As she explains, David W. Pearce was the first economist to use the expression "natural capital" to refer to natural resources and services, or, to use his own words, "the set of all environmental assets" (Pearce, 1988, p. 599). ${ }^{1}$ A few years later, the nascent ecological economics movement (see Costanza, 1991, p. 8, 16-17, 329-330) adopted the concept to support the incorporation of environmental constraints into the economic lexicon, and therefore into economic analysis. Ecological Economics was the journal in which the natural capital concept developed, in many articles dealing with sustainability. For example, in 1992, Fikret Berkes and Carl Folke discussed the relationship between human-produced capital, cultural capital and natural capital, defining the last (p. 2) as the sum of (1) exhaustible resources, (2) renewable resources, and (3) what are called today regulating ecosystem services (climate, hydrological cycles, etc.). This triad became a classic definition of natural capital for many scholars, both inside and outside ecological economics. And, so far, it has achieved wide success - i.e. the natural capital concept has spread throughout the economic literature.

This spread could have been seen as a victory for ecological economists. But, from the middle of the 1990s, some scholars involved in a radical criticism of mainstream economics (see Harribey, 1996; O'Connor and Martinez-Alier, 1998) warned their colleagues about the distortion of natural capital as an operational concept: instead of widening economic analysis to include environmental constraints, the concept was accused of encouraging a narrow vision of the environment, reduced to mere assets with an economic value. Maria Åkerman herself notes this development ( $\AA$ kerman 2003 p. 437; 2005, p. 42).

This controversy actually opposes two

${ }^{1}$ As Nadal (2016, p.65) states, the concept of natural capital already existed in the 1970s, for instance in Schumacher (1973), but with no clear definition. different uses of the natural capital concept, which correspond to the strong and weak positions in the sustainability debate (see Neumayer, 1999). On the one hand, natural capital can be seen as a set of immutable natural items satisfying basic needs. It is then defined as critical - i.e. non-substitutable. As a result, since it is immeasurable using common methods, it cannot be compared in monetary terms with other types of capital, and thus cannot be used in cost-benefit analysis. This strong interpretation of the natural capital concept aims to incorporate natural constraints into economic analysis, through the use of the term "capital", but endowing this capital with particular characteristics (non-substitutability, nonreproducibility, etc.). On the other hand, natural capital can be considered as a set of natural resources or services that need to be consciously managed, but that can be used in standard costbenefit calculations. In this framework, limited substitutability and reproducibility still exist. But this does not prevent monetary valuation and cost-benefit analysis, with theoretical tools coming from capital theory (amortisation, discount rates, etc.). This second approach has led to many monetary valuation studies of resources and ecosystem services, starting with Costanza et al.'s (1997) famous paper published in Nature in 1997. On the other hand, research into critical natural capital also developed, bringing together ecological economists attached to a strong interpretation of the natural capital concept (see for instance Ekins et al., 2003).

Such a controversy about the correct use of the natural capital concept, or rather about the consequences of its use by economists engaged in monetary valuation, needs to be enlightened by a new inquiry into the roots of the concept. In fact, contrary to Akerman's observations, the notion of natural capital, in its modern meaning, appeared in economic literature long before the 1980 s, being used for the first time in a textbook that is almost unknown today, written by Alvin S. Johnson in 1909. This historical moment, which is very little documented, is worth examining because it sheds light on the relationship between the concept of natural capital and economic theory, and it puts current controversies into perspective. The objective of this paper is thus twofold: (i) to complete 
Åkerman's work by paying tribute to Johnson for his neglected role in the history of environmental economics, and (ii) to build on that ancient historical moment to give a new interpretation of contemporary debates.

This article is organised as follows: Section 2 reports the historical inquiry into the natural capital concept. This inquiry produces interesting results with respect to Alvin S. Johnson's writings (Section 3). Section 4 gives some theoretical explanation for these results in relation to the Austrian and American discussions about capital theory. Section 5 shows how this narrative helps interpret current controversies, and makes some concluding remarks about this investigation.

\section{Searching for Natural Capital}

Searching for a concept in the history of ideas may involve two processes: searching for the idea behind the words; or searching for the words themselves. Linguistically speaking, this equates to searching either for the signified, or the signifier. As far as natural capital is concerned, this inquiry sits at the meeting-point of these two perspectives. In other words, it seeks, in the history of economic ideas, the moment when the expression "natural capital" appeared simultaneously with its modern meaning.

As far as the signified is concerned, DesRoches (2015) produced a remarkable piece of work, describing the philosophical characteristics of the conception of nature which is conveyed by the natural capital concept, defined as a set of resources and autonomous productive services. DesRoches carried out his own historical inquiry, and he emphasises the role of classical economists, beginning with Adam Smith and David Ricardo, in changing economists' view of nature. His inquiry is worth reading, but it ignores the role of the word itself. DesRoches reports different authors who do not refer to natural capital as a signifier, but only as a signified. In order to construct a parallel between past and present conceptions of natural capital, it is necessary to go beyond DesRoches' analysis, and to search for the expression itself.

As regards the signifier, searching for the natural capital concept in 18th-, 19th- and 20thcentury economic corpuses in various languages - English, German, French and Spanish ${ }^{2}$ - gives contrasting results. As far as historical encyclopaedias and digitised books and articles may give accurate results for such an inquiry, ${ }^{3}$ the natural capital concept did not appear in a significant manner before the middle of the 19th century.

In the English-language literature, one of the first occurrences of the term may be ascribed to Ebenezer Jones, a British publicist and lampoonist, who, in 1849, wrote an essay on the concentration of landed property and its consequences for social justice and economic efficiency. Jones was close to the socialist movement, and he developed his criticism to denounce the excessive concentration of wealth in the hands of a few people. The expression "natural capital" is used a few times, as a synonym for land (p. 6, 19, 21). In his rhetoric, this expression has the advantage of echoing other kinds of productive capital (machines, tools) owned by the same people. It reinforces the idea that capitalism leads to concentration of wealth in all its forms. Jones's intention and definition of natural capital - as land - remains different from modern meanings. Some years later, in 1864 , reporting on the 5th International Statistical Congress held in Berlin the year before, Samuel Brown uses the term "natural capital" to refer to "land, etc." (p. 205), but places "water and steam power, [and] the principal metals" (p. 205) outside this category. $\mathrm{He}$ gives an approximate definition of the concept, simply listing it among many statistical categories requiring discussion. The same issue arises in a note from the Royal Statistical Society published in 1904, in which the author alerts

\footnotetext{
${ }^{2}$ These languages are the most relevant, since most Scandinavian and Russian authors wrote in German until English took the lead in economic literature after World War II. The Italian "capitale naturale" gives no result.

${ }^{3}$ Searches were made on dictionaries and document databases including JSTOR, BSC, Google Books, the New Palgrave and the Dictionnaire de l'économie politique by Charles Coquelin and Gilbert Guillaumin. This investigation was not designed to be totally comprehensive, but to obtain relevant results about old usage of the concept.
} 
readers to the degradation of "national resources" (p. 688), including men and "natural capital" (land and mines). Mining comes into consideration, but once again without extensive theorisation legitimising the analogy between natural resources and capital.

In the German-language literature, the expression "Naturkapital" is just as scarce. Albert Schäffle, one of the main pioneering thinkers in the Austrian tradition, before Carl Menger and Eugen Böhm-Bawerk, employs it on several occasions in his Die Nationalökonomie (1861), and he does give it some theoretical basis. In his view, "Naturkapital" refers to all natural resources and forces, such as water, light and air, which furnish productive services (p. 43). Here the modern meaning of natural capital comes closer. But Schäffle lacks precision about which resources he places in his "Naturkapital" category. Collective natural goods are included (p. 47), but nothing is stated about a potential link between resource management and asset management. Although Schäffle is cited by Menger $(1871$, p. $54 n, 277 n$, 288，290，293-294，300-301，307，312) and Böhm-Bawerk (1889a, p. 54n, 93n, 292n, 347), his use of the natural capital concept has not been followed up in the Austrian tradition.

During the 19th century, it was probably the French-language literature that made the most use of the natural capital concept. Bastiat (1854, p. 256-257), a leading liberal figure, indicates that the socialist Victor P. Considérant regularly makes use of the expression "capital naturel". In his Théorie du droit de propriété et du droit au travail (1848), Considérant indeed defines "capital naturel" as a synonym of primitive capital ("capital primitif") to refer to the value of land (p. 20-21). This looks like Ebenezer Jones' narrow definition of natural capital - not enough to draw parallels between past and present. For their part, Jean-Baptiste Say and Antoine Augustin Cournot, both eminent 19th century French economists, do not use the natural capital concept. ${ }^{4}$ In the French-language literature, the

${ }^{4}$ It may be noted that Say's definition of the "productive service" provided by "natural agents" (Say, 1814, p. 28) can be related to modern conceptions of nature (see Boisvert, 2015), and Cournot sometimes alludes to potential connections most significant uses of the natural capital concept are to be found in the writings of Auguste and Léon Walras. In the 8th lesson of his Evreux course, given in 1832-1833, Auguste Walras, besides his criticism of classical political economy, introduces the notion of "capital naturel" for the first time, referring to original productive forces: land and labour (A. Walras, 1833 , p. 170). The "natural" epithet here is a synonym of "raw" or "crude", when human beings have not yet transformed their innate capacities and available materials into useful goods. Auguste Walras uses this terminology to differentiate between natural and artificial items, a distinction that he would maintain throughout his writing. ${ }^{5}$ In this respect, as in many others (see Dockès et al., 1990), Léon Walras, the future proponent of general equilibrium, followed his father. In 1860, in his L'économie politique et la justice and in an essay entitled "De la cherté des loyers à Paris", he makes a distinction between artificial capital and natural capital, placing land and working men's capacities into the category of natural capital (Walras 1860a, p. 93-94; 1860b, p. 241-242, $252,265)$. This view fits into a more complex constellation of categories of capital (see Lallement, 2000, p. 460). Refining his nomenclature, Walras (1860b, p. 242) separates land and personal skills, noticing that land may be handed down, unlike personal faculties. But he makes no assumption about a potential link between natural resources and assets, even in his Éléments d'économie politique pure (Walras, 1874) when he continues to talk about "capital naturel" (p. 269-270, 352) to make a contrast with artificial items, ${ }^{6}$ in the same fashion as Auguste Walras did before him (labour being part of natural capital).

Finally, in the Spanish-language literature, the word "capital natural" was employed on very few occasions. Influenced by the French liberal economists, Carreras y Gonzalez (1865, p. 84) reports some uses of the natural capital concept, defined as a synonym of primitive

between capital and natural items (Cournot, 1863, p. 83).

${ }^{5}$ See A. Walras 1837 , p. $350-361 ; 1844$, p. $436 ; 1849$, p. $57 ; 1864$, p. $386,398$.

${ }^{6}$ See also Walras 1861, p. 366; 1865, p. 331. 
capital - i.e. exactly the same as Considérant's use, reported by Bastiat. A few years later, in an essay entitled "Economia politica", Ignacio Ramirez, the famous Mexican writer better known as El Nigromante, employs the expression "capital natural" to refer to the single capital that poor people can make use of, namely their labour $(1889$, p. 6). Ramirez's definition of natural capital therefore does not include natural resources, but is limited to labour.

These various contributions are summarised in the following table (Table 1). It appears that the natural capital concept was used in various language traditions, by authors coming from many different intellectual and social positions. The definitions of natural capital were however not very close to the modern sense - i.e. productive assets.

To summarise, whatever the language tradition and school of thought, searching for the natural capital concept in the 19th century seems to give no satisfactory result to enable us to compare past and present. The beginning of the 20th century offers better results, in particular in the English-language literature, with the writing of Alvin S. Johnson.

\section{Johnson's Introduction to Economics (1909)}

Alvin S. Johnson is essentially known for his participation in the first developments of the New School for Social Research in New York during the 1920s and 1930s. At the beginning of his career as an economist, after graduating from Columbia University under the supervision of John Bates Clark, one of the major American economists of the time, he published three books. The first, Rent in Modern Economic Theory: An Essay in Distribution (1902), was taken from his $\mathrm{PhD}$ dissertation. The second, Introductory Economics (1907), was a textbook like many others published at the time (for a review, see McCrea, 1909, p. 328-330). The third, Introduction to Economics (1909), was an update of the 1907 textbook, with more detailed arguments and examples. Johnson's footprint in the history of economic thought is modest, but there is one criterion whereby he deserves much more interest than he has received: giving the natural capital concept a meaning which turns out to be close to that used today. In 1902, Johnson is not yet talking about natural capital, simply referring to "artificial instruments of production" (p. 41), a term that calls for its complement: natural instruments. He also mentions an analogy between ore stocks and capital (p. 23-24), but he does not use the natural capital concept itself. In 1907, natural capital is still not mentioned, but land is considered as a kind of capital good (p. 194-195), and productivity gains are related to "increase in artificial capital or in available natural resources" (p. 133), a clause that suggests common points between artificial and natural items. It is in 1909 that Johnson finally takes the plunge:

"A generation ago practically all economists restricted the term "capital" to productive wealth that has been produced by industry, such as machines, stocks of materials, etc. Productive wealth, the origin of which cannot be traced to man's industry, was usually classified under the heading "natural agents", or simply under "land", since land is by far the most important good in this class. This terminology is still widely used by economists. In everyday language men speak of investing capital in land, as of investing capital in buildings or machinery. This usage will be followed in this book; wherever it is necessary to distinguish between the two classes of productive wealth, we shall call the one artificial capital, the other natural capital." (Johnson, 1909, p. 197)

At first sight, this is no revolution. In this quotation, however, Johnson not only makes a distinction between artificial capital and natural capital, but he also associates the natural capital concept with the productive power of natural agents, without including labour in the same category. By considering natural capital as the set of natural items that furnish productive services to human beings, Johnson is much closer to recent authors, such as Berkes and Folke (1992), than his predecessors.

$\mathrm{He}$ further remarks that industrial development implies a rise in the number of natural agents available for economic production. On this point, he explains that industrial development comes with an increase, or an accumulation, of natural capital: 
"Until the frontiersmen crossed the Appalachian Mountains, the land of the Mississippi Valley, with the timber upon it and the coal and other minerals beneath its surface, was scarcely to be classed as wealth at all. At best, it was potential wealth, not actual wealth. The settlement of the country and the development of means of communication transformed this potential wealth into an immense fund of productive wealth, or capital. Every increase in population, every improvement in methods of agricultural production, increases the importance, and with it the value, of the natural resources of a country. Measuring the capital represented by these natural resources in terms of value, we see that it is constantly growing with the progress of society." (Johnson, 1909, p. 199)

This rhetoric, completed with other quotations along the same lines (Johnson, 1909, p. 213-214), seems much more familiar to capital theory than to natural resource issues. And it echoes modern debates about the increase or decrease in natural capital - and total capital - in the context of sustainable development (see for instance Pearce and Atkinson, 1993). In that sense, Johnson's contribution seems to provide an accurate first use of the natural capital concept in its current meaning.

At the beginning of the 20th century, Johnson's distinction between artificial capital and natural capital was not perceived with much interest at first. In his review of Johnson's book, published in The Economic Bulletin in 1910, Thomas Nixon Carver, one of the main 1910s Conservationists (see Carver, 1918), indicates that the natural capital concept is indeed new, but does not provide any great theoretical gains, apart from creating new words:

"An interesting development of doctrine is found in the author's conception of capital. [...] [he] squares himself with the more widely accepted view by dividing capital into two classes, natural and artificial, natural capital being nothing more nor less than that which is generally called "land and natural agents". There can be no possible objection to this procedure except that it increases the number of terms and adds nothing to our knowledge." (Carver, 1910, p. 22)
This severe judgment might be interpreted in several ways. Perhaps Carver did not perceive the importance of such a shift, namely from natural resources to natural capital. This shift is not only a form of rhetoric, but also opens up the possibility of using analytical tools that would be placed out of scope by focusing on natural resources or agents (on that point, see Missemer, 2017, chapter 4). Perhaps Carver found Johnson's innovation unsurprising, and therefore not worth praising. This explanation is plausible, since Johnson's proposal did not come out of the blue (see below).

In the 1910s, Frank W. Taussig was one of the first influential economists who appropriated the natural capital concept. In his Principles of Economics (1911), he cites Johnson's Introduction to Economics, and shows no hesitation in using the concept, since it enables a better understanding of natural resource valuation. Taussig's work provides an interesting echo to modern controversy about the monetary valuation of natural agents:

"Pursuing this train of thought further, we might say that capital is of two kinds, artificial and natural. Natural capital is that which has been classed under the general head of "land" or "natural agents"; artificial capital includes all instruments made by man. Natural capital may be highly useful and highly valuable, as in the case of a rich mine or a deep-harbor site. [...] Their valuation is high; their capitalization indicates the existence of a large volume of capital.” (Taussig, 1911, vol. 2, p. 118)

In the 1920s, reading Taussig for his own research, Raymond $\mathrm{T}$. Bye, professor of economics at the University of Pennsylvania, considers the expression "natural capital" almost clumsy (1925, p. 22), but he adopts it (p. 393). In subsequent years, the use of the natural capital concept continues to develop. In his review of Bye's book, Jen P. Jensen (1925) argues that it is part of the "treatment and the conclusions [which] conform substantially to recent orthodox masters" (p. 158). Three years later, in a paper published in the American Economic Review, Clark Warburton places it in the category of "common economic terminology" (1928, p. 7071). The natural capital concept therefore became progressively integrated into economic 
theory in the first third of the 20th century. However, despite this relative success, the concept apparently stopped developing, and remained nearly unused, from the 1930 s to the 1980s, when Pearce finally gave it a successful re-launch. Although this fall from grace might be explained by a shift in economic literature from conservation issues to macroeconomics and econometrics in the 1930s, it would need further investigation to provide a complete explanation.

Returning to Johnson's initial innovation, in addition to the fact that the natural capital concept was indeed coined in the 1900s, the question is: why it did appear at that time? And why in Johnson's work? To answer these questions, it is necessary to place Johnson's contribution in its historical and theoretical context, in order to explain why that first use of the natural capital concept took place at that moment, under those conditions.

\section{Some Explanations for Johnson's Innovation}

The end of the 19th century set the stage for profound changes in economic theory. A few years after the appearance of marginalism in the 1870 s, a whole range of economic mechanisms were updated through a new theory of capital. On this point, the Austrian tradition played a significant role, starting with Menger's Grundsätze der Volkswirtschaftslehre (1871) in which commodities are distinguished according to their situation along the productive chain: consumer goods are considered as 1st-order goods, intermediate goods to produce consumer goods as 2nd-order goods, etc. and original factors of production (labour and land) as the highest-order goods ${ }^{7}$ (1871, p. 56-58). This nomenclature is employed by Böhm-Bawerk (1884, 1889a, 1889b) when considering the

\footnotetext{
${ }^{7}$ Menger uses this terminology to propose a new theory of value, called imputation theory, whereby the value of consumer goods, determined by supply and demand (and therefore by marginal utility), gives the value of 2 nd-order goods, that determines the value of 3rd-order goods, and so on. The imputation theory runs in the opposite direction to the classical theory of value that starts with labour costs, and then continues down to consumer goods.
}

definition of capital in economic theory. Since labour and land are part of the highest order of goods, the third standard factor of production, namely capital, must be a secondary factor in economic processes, different from highest-order goods (1889b, p. 105). As a consequence, capital is defined as goods that are produced to produce other goods:

\begin{abstract}
"[...] capital signifies a complex of produced means of acquisition - that is, a complex of goods that originate in a previous process of production, and are destined, not for immediate consumption, but to serve as means of acquiring further goods.” (Böhm-Bawerk, 1884, p. 6)
\end{abstract}

In Menger's terminology, this means that capital refers to all the goods of intermediate orders, between 1st-order goods and highestorder goods. This is an extensive definition of capital, because it includes heterogeneous goods that do not enter economic processes at the same stage. However, Böhm-Bawerk stresses a common characteristic of all capital goods: they all constitute what he names "roundabout ways" of producing (1889a, p. 18). This famous Austrian definition of capital makes a link between the use of capital goods and productivity: the longer the detour, the more numerous are the capital goods, and the higher is the productivity of the final production process (on this point, see Buechner, 1989).

To respond to these theoretical innovations, American economists proposed their own definitions of capital. Merging all these different concepts in a single phrase has no sense, but two authors deserve attention since they actively participated in the constitution of an American economic tradition, debating with Austrian authors (see Tobin, 1985, p. 28), and because they explicitly influenced Johnson's own vision of capital: John Bates Clark and Irving Fisher.

John Bates Clark $(1888,1891,1899)$ is well known for having introduced marginal productivity into economic theory. Taking inspiration from the Ricardian rent differential principle, he explains that marginal differences in productive efficiency can determine the payment gaps between capital goods. In other words, the Ricardian principle is generalisable to all factors of production: 
"Labor and capital, in current theories, are the antithesis of the typical rent-producer, land. Yet wages in the aggregate constitute the income derived by society from its entire fund of pure labor energy; and interest is, in like manner, the product of a fund of pure capital. Both are differential gains, and completely amenable to the Ricardian law." (Clark, 1891, p. 300)

Unlike Böhm-Bawerk, Clark considers that the productivity of capital does not depend mainly on the duration of production periods, but on the quantity of capital already in existence (1899, p. 139). His allusion to the law of diminishing returns, through the Ricardian rent differential principle, is stressed here. And it results in a very different theory of interest in Clark's scheme compared to that of the Austrians'. ${ }^{8}$ With regard to the classical definition of capital - as an instrument of production, Clark asserts that it causes confusion, placing "tools", "raw materials" and "food for labourers" in the same group (1899, p. 123), whereas they are intrinsically different. To overcome this confusion, he states that capital takes two forms: "capital goods" and the "fund of capital" (1888, p. 9; 1899, p. 117). The former provides the best definition: "capital consists of instruments of production [that] are always concrete and material" (1899, p. 117). This differs from the classical economists' concept inasmuch as "acquired abilities of workmen" (p. 116) are not part of capital. The fund of capital consists of the permanent, abstract and monetary form of capital, and capital goods are its concrete, temporary and physical forms. Ever since this period, this duality has been a permanent feature of controversies about capital in the history of economic thought (see Cohen and Harcourt, 2005).

Beyond Clark's various innovations, it is noteworthy that he uses a wide yet plural definition of capital, not including food or raw

\footnotetext{
${ }^{8}$ Clark emphasises the fact that the rate of interest depends on the marginal product of capital, while the Austrian economists focus on discounting the future (see Rebeyrol, 2000). On other points of difference between Clark and Böhm-Bawerk, see Cohen, 2008.
}

materials, but covering productive tools and machinery, and also productive wealth in general (through the "fund of capital"). Johnson's view of natural capital is not far removed from such a conception: since natural agents constitute productive wealth, they can be included in capital. There is no explicit textual evidence of the shift from Clark's wide view of capital to Johnson's natural capital concept, but what is sure is that Clark exerted a great influence on Johnson, since the latter was a student, then a friend, of the former. In his autobiography, Johnson (1952) writes that he felt "unreserved admiration and loyalty" for his teacher when he was young (p. 123), and that Clark was "the greatest of American theorists" of his time (p. 153). In the prefaces of his early works, he already noted Clark's influence on his own writings (Johnson 1902, p. v; 1907, p. iv-v; 1909 , p. v), and this influence was clearly perceptible through all his arguments, as reported by McCrea (1909, p. 328). Johnson's own choice of an extensive definition of capital, finally arriving at the natural capital concept, is therefore not surprising.

In the controversies about capital at the turn of the 20th century, Irving Fisher (1896, 1897a, $1897 \mathrm{~b}, 1906)$ also played an important part, challenging Clark's conception. ${ }^{9}$ According to Fisher, defining capital with concrete or abstract forms does not work, since capital has many features and cannot be correctly understood in this way. He argues that it is better to define capital as a mere stock of wealth - i.e. as a stock of "material objects owned by human beings" (1906, p. 3). Following Cannan's (1903, p. 14) proposal, Fisher gives an even more extensive definition of capital than Clark. All material objects that are owned at a moment in time are considered to be capital, whatever their intrinsic nature. There is no more connection here with production processes, and that is partly why Fisher and Clark do not share the same definition of capital. Despite his filiation to Clark, Johnson did not completely ignore Fisher's work when developing his own view. In the preface to his 1909 Introduction to Economics, he praises

\footnotetext{
${ }^{9}$ For more on the place of Fisher's conception of capital in the history of economic thought, see Meacci (1989).
} 
Fisher's writings on "rent and capitalisation" (p. v).

Paving the way for the natural capital concept, Fisher's definition of capital leads to a new conception of natural resources in economic theory. Since natural resources are material objects that can be possessed, they are part of wealth. At a given moment in time, a stock of such resources can then be considered as capital (Fisher 1896, p. 534; 1897a, p. 199). On the same grounds, the usual boundaries between economic terms become blurred. In his 1906 book, Fisher suggests that the words "resources" and "assets" are synonymous. He does not specifically talk about natural resources, but, retrospectively, such a semantic convergence might be relevant, in particular as regards Pearce's 1988 definition of natural capital as the "set of all environmental assets" (p. 599). Johnson used the legacy of both Clark's and Fisher's views of capital. He had in mind an extensive definition, with a potential connection to the notion of wealth. In some ways, he synthesised Fisher's matching of resources and assets and Clark's attachment to production processes. As a consequence, capital could be seen as a productive stock of wealth, and natural agents could form part of this definition. The natural capital concept had only to be coined.

In his 1909 contribution, Johnson does not explicitly indicate why natural capital is a meaningful notion, but the present article helps to explain that all the possible conditions, including the Austrian controversy about capital and its aftermath in America, had been met at the time he wrote his textbook. He was the right man at the right moment.

\section{Conclusion: Past and Present}

As already mentioned, in the middle of the 1990s, the natural capital concept was the subject of recurrent debates concerning its correct use in economic theory. Of course, this concept does not belong to any school of thought. And it can be interpreted in various ways. Yet this controversy raises the following questions: Does the natural capital concept stand at the core, or at the periphery, of economics? In other words, is it a challenging concept as
Pearce, Berkes, Folke and others consider? Or is it the artefact of a monetary perspective applied to environmental issues? These questions can be answered in different ways. The historical inquiry conducted in the preceding sections sheds new light on these issues.

Obviously, Johnson's natural capital and today's natural capital do not cover exactly the same range of environmental items. Johnson focused on natural "agents" - i.e. resources and forces. Today, ecosystem services are included; but Johnson did not consider them. However, convergences still exist, since, in both cases, the natural capital concept is a way of encapsulating natural items in a stock of wealth managed by human beings. And both the old and current terms "natural capital" include the idea of something having a productive nature.

Exploring what happened to the natural capital concept in the $1910 \mathrm{~s}$ and $1920 \mathrm{~s}$, after Johnson's initial impetus, gives some insight into present controversies. The natural capital concept did not experience the same long-term success as today, probably because of differences in political and scientific agendas; but when it was employed, it was not at the periphery of economic theory, but at the core. Taussig (1911) was one of the main American economists of the first third of the 20th century. Bye's (1925) book was a canonical neoclassical textbook for many American students, and it was republished several times between the 1920s and the 1950s. As Jensen (1925) and Warburton (1928) underlined, the natural capital concept had become almost a mainstream expression, rather than a revolutionary term.

Going back to the term's origins, Johnson himself was not a revolutionary author. He had been the student of one of the most influential neoclassical economists of his time, John Bates Clark. And Johnson's, 1909 textbook, in which the natural capital concept appeared, was considered as one of the most useful textbooks of the 1900s for all university students, merging Clark's, Marshall's, and Austrian teachings (see Carver, 1910, p. 22-23). Once again, the early history of the natural capital concept did not take place at the periphery of economics, but at its core. The emergence of the concept was the consequence of an extensive definition of capital, initiated by Clark and Fisher, who were 
themselves far from the margins of economic theory. Capital was seen as a stock of wealth, with a monetary value. Natural capital was probably perceived in the same way, insofar as Johnson talks about "measuring the capital represented by these natural resources in terms of value" (1909, p. 199), and about potential "revaluation of natural capital goods" (p. 214).

Bearing this narrative in mind, it should not be surprising that a monetary-valuation shift has been observed in the use of the natural capital concept since the middle of the 1990s. To a certain extent, it has been part of the concept itself since the beginning, though its rebirth in the 1980 s occurred with no reference to those ancient origins. As a result, historically speaking, perhaps the ecological economists have been bolder, in wanting to give a strong, challenging interpretation to the natural capital concept, whereas mainstream economists have opted for a monetary view that is, in the end, more consistent with the deep roots of the concept. But, hopefully, the history of economic thought does not forbid new uses and conceptions that are as legitimate as old ones; it simply helps to understand all that surrounds current issues.

\section{Acknowledgements}

A previous version of this paper was presented at CIRED in November 2015. I thank the participants of this seminar, in particular Philippe Quirion, for their comments. I also thank Sylvère Mateos for assistance in some bibliographical matters. Finally, I am grateful to the editors and reviewers of the journal who gave me sound directions for finishing the article.

\section{References}

Åkerman, M., 2003. What does 'natural capital' do? The role of metaphor in economic understanding of the environment. Environ. Values 12, 431-448.

Åkerman, M., 2005. What does 'natural capital' do? The role of metaphor in economic understanding of the environment. Environ. Educ. Res. 11 (1), 37-52.

Bastiat, F., 1854. Harmonies économiques. 3rd edition. 6. Guillaumin et Cie, Paris (Euvres complètes).

Berkes, F., Folke, C., 1992. A systems perspective on the interrelations between natural, human-made and cultural capital. Ecol. Econ. 5 (1), 1-8.

Böhm-Bawerk, E., 1884. Capital and interest. A Critical History of Economical Theory. MacMillan \& Co, London \& New York (English translation by W. Smart, 1890).

Böhm-Bawerk, E., 1889a. The Positive Theory of Capital. G.E. Stechert \& Co., New York (English translation by W. Smart, 1891 [reprint 1930]).

Böhm-Bawerk, E., 1889b. Une nouvelle théorie sur le capital. Rev. Econ. Polit. 3, 97-124.

Boisvert, V., 2015. Les services écosystémiques: un nouveau concept? In: Thomas, F., Boisvert, V. (Eds.), Le pouvoir de la biodiversité. Néolibéralisation de la nature dans les pays émergents. IRD Éditions \& Quæ, Paris, pp. 215229

Brown, S., 1864. Report on the fifth international statistical congress, held at Berlin, Sept. 6th to 12th, 1863. Assur. Mag. J. Inst. Actuaries 11 (4), 195-224.

Buechner, M.N., 1989. Roundaboutness and Productivity in Böhm-Bawerk. South. Econ. J. 56 (2), 499-510.

Bye, R.T., 1925. Principles of Economics. Alfred A. Knopf, New York.

Cannan, E., 1903. A History of the Theories of Production and Distribution in English Political Economy from 1776 to 1848. 2nd edition. P.S. King \& Son, London.

Carreras y Gonzalez, M., 1865. Tratado didactico de economia politica. Imprenta $\mathrm{y}$ Libreria de M. Guijabro, Madrid.

Carver, T.N., 1910. Review of introduction to economics, by Alvin S. Johnson. Econ. Bull. 3 (1), 21-23. 
Carver, T.N., 1918. Conservation of Human Resources. In: Ely, R.T., Hess, R.H., Leith, C.K., Carver, T.N. (Eds.), The Foundations of National Prosperity. Studies in the Conservation of Permanent National Resources. MacMillan, New York, pp. 273-362.

Clark, J.B., 1888. Capital and its earnings. Publ. Am. Econ. Assoc. 3 (2), 9-69.

Clark, J.B., 1891. Distribution as determined by a law of rent. Q. J. Econ. 5 (3), 289-318.

Clark, J.B., 1899. The Distribution of Wealth. A Theory of Wages, Interest and Profits. MacMillan, New York.

Cohen, A.J., 2008. The mythology of capital or of static equilibrium? The Böhm-Bawerk/Clark controversy. J. Hist. Econ. Thought 30 (2), 151171.

Cohen, A.J., Harcourt, G.C., 2005. Introduction. Capital theory controversy: scarcity, production, equilibrium and time. In: Bliss, C.J., Cohen, A.J., Harcourt, G.C. (Eds.), Capital Theory. 1. Edward Elgar Publishing, Cheltenham \& Northampton, pp. xxvii-xxvlx.

Considérant, V.P., 1848. Théorie du droit de propriété et $d u$ droit au travail. 3rd edition. Librairie Phalanstérienne, Paris.

Costanza, R. (Ed.), 1991. Ecological Economics: The Science and Management of Sustainability. Columbia University Press, New York.

Costanza, R., D'Arge, R., de Groot, R., Farber, S., Grasso, M., Hannon, B., Limburg, K., Naeem, S., O'Neill, R.V., Paruelo, J., Raskin, R.G., Sutton, P., van den Belt, M., 1997. The value of the world's ecosystem services and natural capital. Nature 387, 253-260 (May).

Cournot, A.A., 1981. Principes de la théorie des richesses. In: Jorland, G. (Ed.), Euvres complètes d'Antoine Augustin Cournot, IX, 1863. Vrin \& CNRS, Paris.

DesRoches, C.T., 2015. The World as a Garden. A Philosophical Analysis of Natural Capital in Economics. PhD thesis. University of British Columbia (Under the supervision of Margaret Schabas).

Dockès, P., Goutte, P.-H., Hébert, C., Mouchot,
C., Potier, J.-P., Servet, J.-M., 1990. Introduction générale. In: Dockès, P., Goutte, P.-H., Hébert, C., Mouchot, C., Potier, J.-P., Servet, J.-M. (Eds.), Euvres économiques complètes d'Auguste et Léon Walras. 1. Economica, Paris, pp. ix-xlvii.

Ekins, P., Simon, S., Deutsch, L., Folke, C., De Groot, R., 2003. A framework for the practical application of the concepts of critical natural capital and strong sustainability. Ecol. Econ. 44, 165-185.

Fisher, I., 1896. What is capital? Econ. J. 6 (24), 509-534.

Fisher, I., 1897a. Senses of "capital". Econ. J. 7 (26), 199-213.

Fisher, I., 1897b. The rôle of capital in economic theory. Econ. J. 7 (28), 511-537.

Fisher, I., 1906. The Nature of Capital and Income. MacMillan \& Co., London \& New York.

Harribey, J.-M., 1996. Développement soutenable et réduction du temps de travail. Analyse critique appliquée au cas de la France. $\mathrm{PhD}$ thesis. Université Paris 1 (Under the supervision of Serge Latouche).

Jensen, J.P., 1925. Review of principles of economics, by Raymond T. Bye. Ann. Am. Acad. Pol. Soc. Sci. 119, 158.

Johnson, A.S., 1902. Rent in Modern Economic Theory: An Essay in Distribution. American Economic Association \& MacMillan, New York.

Johnson, A.S., 1907. Introductory Economics. School of Liberal Arts and Sciences for NonResidents, New York.

Johnson, A.S., 1909. Introduction to Economics. D.C. Heath \& Co., Boston (MA).

Johnson, A.S., 1952. Pioneer's progress. An Autobiography. The Viking Press, New York.

Jones, E., 1849. The Land Monopoly, the Suffering and Demoralization Caused by it; and the Justice \& Expediency of its Abolition. Chas, Fox, London.

Lallement, J., 2000. Prix et équilibre selon Léon Walras. In: Béraud, A., Faccarello, G. (Eds.), 
Nouvelle histoire de la pensée économique. 2. La Découverte, Paris, pp. 449-497.

McCrea, R.C., 1909. Some recent text-books in economics. Q. J. Econ. 23 (2), 324-344.

Meacci, F., 1989. Irving fisher and the classics on the notion of capital: upheaval and continuity in economic thought. Hist. Polit.Econ. 21 (3), 409-424.

Menger, C., 1871. Principles of Economics. Ludwig von Mises Institute, Auburn (English translation by J. Dingwall \& B.F. Hoselitz, 1976 [reprint 2007]).

Missemer, A., 2017. Les Économistes et la fin des énergies fossiles (1865-1931). Classiques Garnier, Paris.

Nadal, A., 2016. The natural capital metaphor and economic theory. Real-World Econ. Rev. 74, 64-84.

Neumayer, E., 1999. Weak versus strong sustainability. Exploring the Limits of Two Opposing Paradigms. Edward Elgar Publishing, Cheltenham \& Northampton.

O’Connor, M., Martinez-Alier, J., 1998. Ecological Distribution and Distributed Sustainability. In: Faucheux, S., O'Connor, M., van der Straaten, J. (Eds.), Sustainable Development: Concepts, Rationalities and Strategies. Springer, London, pp. 33-56.

Pearce, D.W., 1988. Economics, equity and sustainable development. Futures 20 (6), 598605.

Pearce, D.W., Atkinson, G.D., 1993. Capital theory and the measurement of sustainably development: an indicator of 'weak' sustainability. Ecol. Econ. 8 (2), 103-108.

Ramirez, I., 1889. Economia politica. Obras de Ignacio Ramirez. tomo II. Oficina Tip. de la Secretaria de Fomento, Mexico, pp. 3-168.

Rebeyrol, A., 2000. Répartition, intérêt et théorie du capital. In: Béraud, A., Faccarello, G. (Eds.), Nouvelle histoire de la pensée économique, tome 2. La Découverte, Paris, pp. 524-571.

Royal Statistical Society, 1904. Notes on economic and statistical works. J. R. Stat. Soc. 67 (4), 684-732.
Say, J.-B., 1814. Traité d'économie politique. 2nd ed. tome 1. A.-A. Renouard, Paris.

Schäffle, A., 1861. Die Nationalökonomie. Otto Spamer, Leipzig.

Schumacher, E.F., 1973. Small is Beautiful. Economics as if People Mattered. Blond and Briggs, London.

Taussig, F.W., 1911. Principles of Economics. 1 \& 2. MacMillan, New York.

Tobin, J., 1985. Neoclassical theory in America: J. B. Clark and Fisher. Am. Econ. Rev. 75 (6), 28-38.

Walras, A., 1833. Cours d'économie politique dispensé à Évreux (1832-1833). In: Dockès, P., Goutte, P.-H., Hébert, C., Mouchot, C., Potier, J.-P., Servet, J.-M. (Eds.), Euvres économiques complètes d'Auguste et Léon Walras. 3. Economica, Paris, pp. 65-320 (2005).

Walras, A., 1837. Cours d'économie politique dispensé à l'Athénée Royal de Paris (18361837). In: Dockès, P., Goutte, P.-H., Hébert, C., Mouchot, C., Potier, J.-P., Servet, J.-M. (Eds.), Euvres économiques complètes d'Auguste et Léon Walras. 3. Economica, Paris, pp. 345-382 (2005).

Walras, A., 1844. Esquisse d'une théorie de la richesse. In: Dockès, P., Goutte, P.-H., Hébert, C., Mouchot, C., Potier, J.-P., Servet, J.-M. (Eds.), Euvres économiques complètes d'Auguste et Léon Walras. 1. Economica, Paris, pp. 427-442 (1990).

Walras, A., 1849. Théorie de la richesse sociale. Guillaumin et Cie, Paris.

Walras, A., 1864. Cours d'économie politique dispensé à Pau (1863-1864). In: Dockès, P., Goutte, P.-H., Hébert, C., Mouchot, C., Potier, J.-P., Servet, J.-M. (Eds.), Euvres économiques complètes d'Auguste et Léon Walras. 3. Economica, Paris, pp. 383-413 (2005).

Walras, L., 1860a. De la cherté des loyers à Paris. In: Dockès, P., Goutte, P.-H., Hébert, C., Mouchot, C., Potier, J.-P., Servet, J.-M. (Eds.), Euvres économiques complètes d'Auguste et Léon Walras. 7. Economica, Paris, pp. 91-110 (1987). 
Walras, L., 1860b. L'économie politique et la justice. In: Dockès, P., Goutte, P.-H., Hébert, C., Mouchot, C., Potier, J.-P., Servet, J.-M. (Eds.), Euvres économiques complètes d'Auguste et Léon Walras. 5. Economica, Paris, pp. 145-313 (2001).

Walras, L., 1861. Théorie critique de l'impôt. In: Dockès, P., Goutte, P.-H., Hébert, C., Mouchot, C., Potier, J.-P., Servet, J.-M. (Eds.), Euvres économiques complètes d'Auguste et Léon Walras. 5. Economica, Paris, pp. 365-413 (2001).

Walras, L., 1865. Compte rendu de Le crédit et les finances, par Victor Bonnet. In: Dockès, P., Goutte, P.-H., Hébert, C., Mouchot, C., Potier,
J.-P., Servet, J.-M. (Eds.), Euvres économiques complètes d'Auguste et Léon Walras. 13. Economica, Paris, pp. 331-334 (2000).

Walras, L., 1874. Éléments d'économie politique pure. In: Dockès, P., Goutte, P.-H., Hébert, C., Mouchot, C., Potier, J.-P., Servet, J.-M. (Eds.), Euvres économiques complètes d'Auguste et Léon Walras. 8. Economica, Paris (1988).

Warburton, C., 1928. Economic terminology: factors of production and distributive shares. $\mathrm{Am}$. Econ. Rev. 18 (1), 65-74.

\begin{tabular}{|c|c|c|c|c|}
\hline Author (year) & Language & $\begin{array}{l}\text { Social } \\
\text { situation }\end{array}$ & School of thought & $\begin{array}{l}\text { Definition of } \\
\text { natural capital }\end{array}$ \\
\hline Jones (1849) & English & Lampoonist & Socialist & Land \\
\hline Brown (1864) & English & Statistician & l & $\begin{array}{l}\text { Land, undefined } \\
\text { resources }\end{array}$ \\
\hline $\begin{array}{l}\text { Royal Statistical } \\
\text { Society (1904) }\end{array}$ & English & Statistician & / & Land, mines \\
\hline Schäffle (1861) & German & $\begin{array}{l}\text { Social Scientist } \\
\text { and Politician }\end{array}$ & Pre-Austrian & $\begin{array}{c}\text { Natural resources } \\
\text { and forces }\end{array}$ \\
\hline Considérant (1848) & French & $\begin{array}{c}\text { Philosopher and } \\
\text { Economist }\end{array}$ & Socialist & Land \\
\hline Bastiat (1854) & French & $\begin{array}{l}\text { Economist and } \\
\text { Politician }\end{array}$ & Liberal & Land \\
\hline A. Walras (1833) & French & Economist & Post-Classical & Land, labour \\
\hline L. Walras (1860) & French & Economist & $\begin{array}{l}\text { Neo-Classical (defines } \\
\text { himself as a Socialist) }\end{array}$ & Land, labour \\
\hline $\begin{array}{c}\text { Carreras y Gonzalez } \\
(1865)\end{array}$ & Spanish & $\begin{array}{l}\text { Economist and } \\
\text { Writer }\end{array}$ & Liberal & Land \\
\hline Ramirez (1889) & Spanish & $\begin{array}{c}\text { Writer and } \\
\text { Political Activist }\end{array}$ & Liberal & Labour-force \\
\hline
\end{tabular}

